\title{
R\&D spillovers from international student flows: a brics analysis
}

\author{
Matheus Dall'agnol $^{\mathrm{a}}$ (D), Diogo Ferraz ${ }^{\mathrm{a}, \mathrm{b} *}$ (D), Naijela da $\operatorname{Costa}^{\mathrm{c}}$ (D), Herick Fernando Moralles ${ }^{\mathrm{c}}$ (D), \\ Daisy Aparecida do Nascimento Rebelatto ${ }^{\mathrm{a}}$ \\ aDepartamento de Engenharia de Produção, Universidade de São Paulo, São Carlos, São Paulo, Brasil \\ bLehrstuhls für Innovationsökonomik, Universität Hohenheim, Stuttgart, Germany \\ 'Departamento de Engenharia de Produção, Universidade Federal de São Carlos, São Carlos, São Paulo, Brasil \\ *diogoferraz@alumni.usp.br
}

\begin{abstract}
Paper aims: to analyze the international flow of students - both from developed and underdeveloped countries - and to observe their significance for the productivity gains of the country of origin of these students.

Originality: The main contributions to the literature are the understanding of how student flows affect countries' economic growth, as well as to verify the systematic differences between the contribution of international student flows to economic growth between developed and underdeveloped countries.

Research method: This empirical study performed using a data set of 87 countries, during 2001-2012 yields results that are in accordance with previous literature, supporting the hypothesis of international student flows as a significant channel of R\&D spillovers from developed countries. The paper used econometric models already tested by previous studies.

Main findings: The results show that BRICS countries may benefit more than other countries from such internationalization initiatives.

Implications for theory and practice: The mobility of international students is currently an important political issue in the world. These formal or informal links between agents from diverse countries result in an exchange of ideas, experiences and knowledge potentially generating new business opportunities for developing economies.
\end{abstract}

Keywords:

Productivity. Developed countries. Underdeveloped countries. Economic growth.

How to cite this article: Dall'agnol, M., Ferraz, D., Costa, N., Moralles, H. F., \& Rebelatto, D. A. N. (2019). R\&D spillovers from international student flows: a brics analysis. Production, 29, e20190054. https://doi.org/10.1590/0103-6513.20190054

Received: June 10, 2019; Accepted: October 7, 2019.

\section{Introduction}

Several studies have devoted considerable effort to identify the key variables that influence technological innovation in a country or a region. Topics such as foreign trade, foreign direct investment, education, and human capital, among others, have been extensively studied and constitute the main research strand on the subject.

For Konno (2016), knowledge is the most important and representative externality in economics. Moreover, according to Fujiwara (2017), knowledge spillover is an important mechanism for countries' endogenous growth, assisting mainly small businesses and young people, which can complement the lack of R\&D through knowledge spillovers.

Although the role of education in the determination of the technological level of a country is studied intensely, it is noted that few studies have related the economic growth with possible contributions from the international flow of students, especially in developing countries. With increasing globalization, the international flow of students tends to become increasingly significant: according to OECD reports, between 2000 and 2011, 
the number of international students more than doubled, with approximately 4.5 million tertiary students out of their country of origin.

Much of the economic growth due to the internationalization of the economy is due to the effects of spillover (diffusion or externality) of knowledge between the countries connected internationally. The appropriation of external know-how, whether through international trade, foreign direct investment or education, constitutes the main form of international influence in the growth of the technological level of a country.

Researchers in developed countries have studied the technological change and growth relationship extensively (Griffith et al., 2006; Hall \& Mairesse, 1995; Harhoff, 1998; Verspagen, 1995), but researchers in developing countries have not contributed much to this debate. Growth in these countries depends more heavily on capital investment than knowledge and learning (Waheed, 2017; Moralles et al., 2013; Moralles \& Rebelatto, 2016).

Increasing productivity is the fastest way to achieve economic growth and social well-being, since such production gains reflect the full effectiveness of the productive sector as well as the degree of development of society (Felema et al., 2013; Ferraz et al., 2018a). Thus, Total Factor Productivity (TFP) is intended to indicate how efficiently the economy combines all its resources to generate output. From this conceptualization, the dynamics of the indicator is a result of the technological progress of the economy (Messa, 2013).

Multinational firms have higher productivity due in part to fewer financial constraints (Feenstra et al., 2014) or more international technology spillover (Keller \& Yeaple 2009), and hence export more (Yu, 2017). The intricate mechanism of how technologies disseminate through countries has been extensively studied in the three main channels: the international trade (Grossman \& Helpman, 1991), foreign R\&D stock (Coe \& Helpman, 1995) and to Foreign Direct Investments (FDI) (Bitzer \& Kerekes, 2008).

Many discussions have also attributed important roles to Human Capital acquisition and circulation. Some economists believe that openness to international exchange contributes to the dynamic performance of a country (Grossman \& Helpman, 1991). Le (2008) discussed how migration patterns may influence knowledge dissemination, and within the same scope, Park (2004) was the first to discuss how the international flow of tertiary students might influence knowledge spreading. While Park's article focused mainly on developed countries and the spillover behavior among them, Le (2010) broadened the analysis, including developing countries as possible beneficiaries from spillovers through internationalization efforts. Both articles corroborated the importance of such student flows for the country's productivity. Though both studies may complement each other, it is important to notice that new data has been provided, and the study first proposed by Park (2004) and Le (2010) can be extended.

Within this context, the aim of this paper is to analyze the international flow of students - both from developed and underdeveloped countries - and to observe their significance for the productivity gains of the country of origin of these students. Nevertheless, it aims to have a more detailed view of the relationship between internationalization of students and productivity gains in developed countries and BRICS. The paper will use econometric models already tested, such as those of the Park and le studies cited above.

This article seeks to understand two questions: Does the international flow of students affect the economic growth of countries? Are there systematic differences between the contribution of international student flows to economic growth between developed and underdeveloped countries? What is the return of internationalization incentive programs to BRICS countries?

These are relevant questions because, according to Konno (2016), managers, engineers and scientists acquire and exchange new information in order to increase productivity. The author states that the heterogeneity of the productive structure is important in the spillover processes of knowledge. In this way, the international flow of students in different areas can contribute to increase network heterogeneity, disseminate knowledge and increase productivity and economic growth. Furthermore, according to Qiu et al. (2017), the spillover of advanced knowledge of developed countries can influence the learning and innovation capacities of enterprises in developing countries. Therefore, the international flow of students can contribute to this process.

The importance of this study occurs because, according to Luintel \& Khan (2017), in emerging countries, R\&D expenditure grew 8.6\% a year in real terms in 1992-2010. Over the same period, growth in OECD countries was $2.8 \%$ per year. In addition, emerging countries' share of R\&D spending increased from 12 percent in 1992 to 26 percent in 2010, and their share of patent applications rose from 11 percent to 36 percent.

According to Qiu et al. (2017) and Zhang et al. (2013), governments in developing countries have emphasized international university partnerships to improve the global position of national universities, cultivate greater scientific advances, and finally catch up in developed countries. This is an important issue associated with the international flow of students, since international inter-university collaboration is significantly associated with the innovation production of local firms.

It is intended to contribute with this research to a more robust understanding of the contribution of these students to the productivity, given the increasing integration among higher education centers. Nevertheless, there 
is a keen interest on the part of countries - which, through public policies - can encourage the internationalization of students, if this is a path that has a positive return to the country's productivity. In particular, the BRICS are seen as a group of countries of essential analysis: because they are populous countries; and, they have a huge potential to send students abroad. It is also worth noting the initiatives already in place in these countries, such as the Brazilian Science without Borders program - in the Brazilian case, created with a view to precisely the greater internationalization of students in the country; and examples of the Chinese government, which since 1978 with Deng Xiaoping signaled the interest of internationalizing students as a means of increasing the know-how available to Chinese society (Chen, 2011).

This paper is divided in six sections: the first one is the introduction, the second is the bibliographic review necessary for this study, the third the methodology used, in the fourth section the results are found, and in the fifth and sixth sections, the conclusions and bibliographical references, respectively.

\section{Literature review}

\subsection{Spillovers and international student flows}

Effects of spillover occur when firms or individuals impose costs or benefits on others outside the specified market (Nordhaus \& Samuelson, 2012). Weil (2012, p. 195) defines spillover effects as "[...] an incidental effect of some economic activity on which no compensation effect is provided". Authors such as Audretsch \& Feldman (1996) and Qiu et al. (2017) consider the spillover of knowledge as a source of innovation and regional economic growth. According to Konno (2016), knowledge spillover has a significant impact on economic growth and business productivity, and this process of propagation between firms can be represented as a process in complex networks.

The spillovers of Marshall-Arrow-Homer (MAR), in which spillovers are determined in particular by location, not by factors such as the level of economic activity (Baldwin et al., 2005). There are also Jacobian spillovers, which assume that positive externalities occur between technologies and distinct industrial sectors (Breschi \& Lissoni, 2001). While MAR type spillovers occur especially among a common industry, Jacobian spillovers relate to the diversity of industries in a given area (Carlino et al., 2001).

According to Marshall (1961), there is a concentration of companies within a region, because proximity facilitates the exchange of knowledge spillovers between companies, thus generating the growth of this industry in the region. The extent to which spillovers can be properly used is closely related to geography and spatial arrangement. Baumont et al. (2001) affirm that the growth rate of a region is influenced positively by the neighboring regions. The results of Wang \& Wu (2016) confirm that geographical proximity plays a significant role in the spillover and diffusion of knowledge.

Geographical spillovers can also occur between regions of the same country. The industrial policy pursued by the Deng Xiaoping era in China, which favored the industrial development of the coastal provinces, was based on the assumption of geographic spillovers from the coastal regions to the most internal regions of the country (Brun et al., 2002).

Knowledge spillovers were discussed by Grossman \& Helpman (1991), who detected that an important channel of distribution and dissemination of knowledge spillovers stems from international trade between countries, in coexistence with geographic spillovers. Numerous articles later corroborated the thesis of Grossman \& Helpman (1991), for example, Spulber (2008), Madsen (2007), Mendi (2007), Cameron et al. (2005).

Coe \& Helpman (1995) discussed the possibility of a country's Total Factor Productivity (TFP) not only depend on its own internal R\&D capital but also on foreign R\&D capital. Estimates of the authors showed that the spillovers of $R \& D$ from external sources were more significant the greater the opening of the country to international trade. Several studies corroborate with Coe \& Helpman (1995) (Lichtenberg \& Pottelsberghe de la Potterie, 1998; Haaland \& Kind, 2008; Cameron et al., 2005; Bitzer \& Geishecker, 2006; Bayoumi et al., 1999).

Tang \& Koveos (2008) state that the most significant form of spillovers occurs through intangible trade, with the exchange of physical products less important for the spillovers. There are authors who discard the importance of intermediate product flows as disseminators of R\&D spillovers, for example, proving the existence of these spillovers even among countries that did not directly engage in bilateral trade (Lumenga-Neso et al., 2005). Lee (2005) refutes the idea that indirect effects are indeed significant, stating that the direct effect of international trade has been increased with increasing use of the internet.

The hypothesis of education as one of the drivers of economic growth is widely accepted in the academic literature (Glaeser et al., 1995; Lin, 2003; Baldacci et al., 2008; Seetanah, 2009). However, there is no consensus 
regarding the educational level that provides the highest returns on investments (Oketch, 2006; Self \& Grabowski, 2003, 2004; Zhang \& Zhuang, 2011).

The effects of the spillovers mentioned above can be taken together. Narula \& Marin (2003) studied the spillovers related to the FDl, concluding that these were only significant when the companies had enough internal know-how to absorb the knowledge coming from these spillovers. According to Cohen \& Levinthal (1990, p. 128), the absorbing capacity is defined as "the ability of prior knowledge to recognize the value of new information, to assimilate it, and to apply it for commercial purposes". In this sense, although the knowledge spillovers are important for innovation, R\&D increases the ability of firms to absorb and use knowledge generated elsewhere (Cohen \& Levinthal, 1990; Griffith et al., 2004; Abubakar \& Mitra, 2017; Ferraz et al., 2018b).

Abubakar \& Mitra (2017) exemplifies a company where R\&D employees are not involved in scientific research. This company tends to ignore the presence of scientific research available from local universities and local companies. On the other hand, a company with research-enabled employees is more likely to absorb the knowledge available at local universities and the products developed by its local rivals.

The high absorptive capacity allows organizations to manage external knowledge more efficiently and stimulate innovative outputs (Escribano et al., 2009). The nature of external information is relevant to the absorption of it, domestic technology is more easily appropriate than foreign technology (Li, 2011).

The significance of the spillovers from FDI are closely related to the absorptive capacity (Borensztein et al., 1998; Liu \& Buck, 2007). This is linked to the company's human resources (Vinding, 2006). Human Capital directly influences the speed with which foreign technology is internalized by the organization (Benhabib \& Spiegel, 1994). Griffith et al. (2003) show that domestic R\&D investment affects both innovation and absorptive capacity, unlike many other studies that neglect the R\&D effect of creating this capability.

Many works involve the relationship between flow of people and the dissemination of knowledge. Le (2010) has aimed at providing evidence of how developing countries might benefit from the international students' flow, there is a particular set of developing countries that require special attention: the BRICS countries. Le (2008) argues that worker mobility transfers technology across borders, arguing that because of the spillovers related to such migration, a "brain circulation" is more likely than a "brain drain" itself.

According to Fujiwara (2017), the mobility of workers' knowledge positively impacts the creation of new enterprises and the increase of productivity. This is because the mobility of the workforce makes it possible to transfer knowledge from stable and mature firms to young firms, especially in high technology sectors.

Maurseth \& Verspagen (2002) found that patent citations occur more frequently between regions belonging to the same country and that are in geographical proximity. Fischer \& Varga (2003) analyzed the importance of spillovers of geographically mediated knowledge from university research activities. They confirmed the presence of geography-mediated university spillovers that transcend the spatial scale of political districts. Wennberg et al. (2011) have verified the transfer of knowledge from academic research that involves the indirect flow to entrepreneurship. They proved that commercial knowledge gained by industry experience is more valuable to business performance compared to the academic knowledge gained by additional research experience at a university.

Fritsch \& Franke (2004) analyzed the impact of knowledge spillovers and cooperation in R\&D on innovation activities. They found significant differences among regions in productivity of R\&D activities, interregional differences may be more or less explained by R\&D spillovers from other R\&D activities by actors located in the same region, and R\&D cooperation plays only a minor role as a means of knowledge spillovers.

Ponds et al. (2010) found that the impact of academic research on regional innovation is not only mediated by geographical proximity, but also by the networks stemming from university industry collaboration. Rodríguez-Gulias et al. (2017) demonstrates that new hi-tech companies can benefit from proximity to universities because of the knowledge spillovers generated.

Our paper focus in the international flow of students (especially tertiary) that can relate to the spillovers of $R \& D$. When we consider the flow of these as an important R\&D transmitter and prove its relevance in a statistical way, the role of trade as a distribution channel for spillovers loses its strength (Park, 2004). The international flow of students was an important source of knowledge dispersion from developed to developing countries (Le, 2010).

\subsection{Total Factor Productivity - TFP}

The TFP is an implicit part of the circular income model present in economic theory: the price and quantity of products and services sold to consumers equals the remuneration of factors involved in the production of these goods and services (Hulten, 2001; Ferraz et al., 2018a). According to Comin (2006, p. 1), the TFP can 
be defined as "[...] the portion of the output not explained by the quantity of inputs used in its production". In neoclassical models, the contribution of technological progress is usually measured by the TFP, as follows (Acemoglu, 2009; Aghion \& Howitt, 2009). Considering a production function such as Cobb-Douglas, we have:

$$
Y=A K^{\alpha} L^{1-\alpha}
$$

Or, similarly,

$$
Y=A K^{\alpha_{k}} L^{\alpha_{L}}
$$

In that the indices $\alpha_{K}$ and $\alpha_{l}$ denote the relative contribution of the capital and labor factors, respectively, to the final output. It is observed that parameter A illustrates how productive an economy is in the use of all its factors of production. It is therefore the TFP:

$$
A \equiv T F P
$$

By showing the growth rates of each of the variables, we obtain:

$$
g \equiv \frac{\dot{Y}}{Y}, g_{k} \equiv \frac{\dot{K}}{K} \text { e } g_{L}=\frac{\dot{L}}{L}
$$

Finally, the TFP can be found by means of Equation 5:

$$
T F P=g+\alpha_{k} g_{k}+a_{L} g_{L}
$$

Alternatively, the output growth rate can be expressed as:

$$
g=\frac{T \dot{F} P}{T F P}+\alpha \frac{\dot{k}}{k}
$$

Where $k=\frac{K}{L}$ is defined as the capital stock per worker. Thus, it can be noted that the growth of an economy is due to the growth of its technological level, measured by the TFP, and by the "capital-intensive" component, measured by the variable $k$. Rewriting Equation 7, so that one can use the principles of growth accounting from a observed growth rate of output:

$$
\frac{T \dot{F} P}{T F P}=g-\alpha \frac{\dot{k}}{k}
$$

The rate of growth of the TFP is the residual obtained after the subtraction of the growth of the term "capital-intensive" from the observed output growth rate. This measure of TFP, shown in equation 10, is called the residue of Solow.

Although TFP is an important variable in the long-term growth of the last decade, little is known about the factors that drive growth. Madsen (2008) argues that the stock of international patents is highly influential in economic growth, and, together with the knowledge spillovers stemming from international trade, an important generator of TFP growth. Bauer (1988) decomposes the TFP growth into three variables: scale, efficiency and technological progress, also using a cost approach.

Human Capital was considered an important factor for a precise measurement of the TFP, and its absence can lead to errors in the measurement of productivity and efficiency (Maudos et al., 1999). Finally, there are numerous articles that relate the sources of TFP growth to variables related to: finance (Jeong \& Townsend, 2007), R\&D (Abdih \& Joutz, 2006), public investment (Ferrara \& Marcellino, 2000), spatial patterns (Abreu et al., 2004), infrastructure, competition, trade openness and institutions (lsaksson, 2007).

In the context of endogenous growth models, Atella \& Quintieri (2001) puts in check the consummate relationship between R\&D variables with the TFP. Using an Italian case study, the authors showed that R\&D effects on TPF depend on: (1) the way in which the production function is defined; (2) the number of assumptions used to estimate Solow residues; (3) the level of aggregation of the data used for the empirical analysis. Similarly, Abdih \& Joutz (2006) inferred a small impact of the knowledge stock on the TFP growth: around $10 \%$, indicating an important role of knowledge spillovers in determining the TFP.

The TFP is widely used in the economic literature as one of the main factors involved in convergence between countries. While absolute and conditional convergence is statistically significant in some articles 
(Miller \& Upadhyay, 2002), technological convergence is related to Human Capital in others (Di Liberto et al., 2008). Regarding the role of spillovers, although it has contributed to the convergence of the TFP between OECD countries, these have been distributed quite unequally across countries, with the United States, Japan and the Scandinavian countries being the main beneficiaries of the spillovers generated by trade in the last century (Madsen, 2007). Similarly, the international stock of patents is of great importance for economic growth and for reducing the dispersion of income levels between countries (Madsen, 2008).

The TFP has an extensive applicability: several articles seek to study how this variable influenced the intense growth of East Asian countries between 1960 and 1990 (Chen, 1997; Felipe, 2000). In this paper, we present the results of the literature on the importance of the TFP in different sectors of the economy, such as manufacturing and agricultural (Coelli \& Rao, 2005; Kalirajan et al., 1996).

With the predominance of Endogenous Growth Theories, one observes the importance of Human Capital for productivity growth and as one of the main factors that influence the Total Factor Productivity (TFP) of a country (Frantzen, 2000; Park, 2006). There are two ways in which Human Capital can influence the growth of the TFP: in the direct way, through the increase of domestic activities focused on innovation; and, by the indirect form, through the spillover effects of Human Capital (Fleisher et al., 2010).

The effects of Human Capital, both on the increase of the TFP and on its repercussion on economic growth, are still gaps: Cameron et al. (2005) affirm that Human Capital has no significant effect on productivity growth per se. However, the same authors affirm that there is an important relationship between economic growth and Human Capital, which suggests that the effect of this occurs through private rates of return. There are authors who defend the hypothesis that spillovers from Human Capital have in fact no practical validity (Rudd, 2000; Wolff, 2000).

The TFP measurement form is addressed in the literature: Lipsey \& Carlaw (2000) affirm that the TFP does not measure all the technological changes that have occurred, but only those that come from externalities and scale effects. Also, according to the authors, the TFP does not adequately capture the effects of technological changes on growth, firm value, quantity of technology embedded in physical products, among others. Similarly, Aiyar \& Dalgaard (2005) found distinct TFP values depending on the method used for their measurement. In the extreme, technological changes can occur even with an unchanged TFP value (Lipsey \& Carlaw, 2004).

Baier Junior \& Tamura (2002), although they do not question the methodology of calculation of the TFP, affirm that it is not an essential variable in the economic growth: with an analysis of data of 145 countries that extend for more than a century, the authors attest that only about 3\% of the average output growth per capita is associated with the growth of the TFP.

\section{Empirical framework}

The applied method follows Le (2010), which analyzes whether the international flow of students between developed and underdeveloped countries contributes significantly to the occurrence of R\&D spillovers. The choice of the model proposed by Le, to the detriment of the one carried out by Park (2004), is due to the greater likelihood between the present article and the study proposed by Le (2010).

Even though Park (2004) did a similar study and precedes Le's article, the author applied his method only among developed countries. Note that this approach does not work to developing countries, for example, Brazil. On the other hand, Le (2010) developed his model with 76 developing countries over the 1998-2005 period, which shows a best fit to our research problem. Moreover, Le (2010) model has been applying to other studies, for example, to the African countries (Le, 2012). The author found that student flows effectively facilitate international technology diffusion from developed countries to developing regions in Africa (Belitz \& Mölders, 2016). For this reason, we justify our choice to the Le (2010) model.

Therefore, the foreign R\&D capital stock is defined as:

$$
S F_{i t}^{f}=\sum_{j=1}^{23} \frac{f_{i j t}}{n_{j t}} * S D_{j t}
$$

where $S F_{i t}^{f}$ is the foreign R\&D capital stock, $f_{i j t}$ is defined as the number of tertiary students from country $i$ studying in developed country $j$ at time $t ; n_{j t}$ is the total number of tertiary students in developed country $j$ at time $t$; and $S D_{j t}$ is the total R\&D expenditure of developed country $j$ at time $t$.

The variable, following the previous literature, is lagged two years in order to allow for time spent studying, working and returning. This paper does not consider a three year moving average, as it tries to capture the variable effects without data manipulation, being a non-interventional exploratory analysis. 
Other possible channels of R\&D spillovers are considered, such as the one from international trade. The variable $S F_{i t}^{m}$ is defined on Equation 9.

$$
S F_{i t}^{m}=\sum_{j=1}^{23} \frac{m_{i j t}}{y_{j t}} * S D_{j t}
$$

where $m_{i j t}$ is the value of imported goods from developed country $j$ by the country $i$ at time $t . y_{j t}$ is the developed country $j$ 's GDP at time $t$; and $S D_{j t}$ is again the total R\&D expenditure of developed country $j$ at time $t$. The regression analysis is defined as:

$$
T F P=g\left(S F_{i t}^{f}, S F_{i t}^{m}, \frac{M_{i t}}{Y_{i t}}, \frac{F_{i t}}{L_{i t}}\right)
$$

where TFP is the total factor productivity; $S F_{i t}^{f}$ is the foreign R\&D capital stock; $S F_{i t}^{m}$ is the foreign R\&D capital due to imports; $\frac{M_{i t}}{Y_{i t}}$ is the ratio of imports to GDP, and $\frac{F_{i t}}{L_{i t}}$ is the total number of tertiary students from country's $i$ studying abroad, divided by its population.

This study uses data from 87 countries (Appendix A), ranging from 2001 to 2012. Data for the number of tertiary students at each country was taken from UNESCO's Institute for Statistics (UIS). The R\&D's expenditure was gathered from three different sources: UIS; OECD Statistical Database; and, the World Bank. Regarding data about international trade, it was taken from the UN Comtrade database. Measurements of TFP were collected from The Conference Board. Lastly, national account's figures were gathered from UN's Statistics Database.

The BRICS countries representing 42\% of the world's population, as well as $20 \%$ of world GDP, these countries may be especially affected by the increasing interconnectedness between nations, and the international student's flow might be an important channel of R\&D spillovers from developed economies

As the study encompasses several databases with different time series, we chose to work with a series that was common to all databases, and that there was a significant amount of data available. Thus, the time series considered in the work starts in 2001 and ends in 2015- $t=2001, \ldots, 2015$.

Also, it is important to note a significant difference between the variables obtained by le and those considered in this paper: while Le (2010) uses the stock of TFP for econometric computations, the present paper uses the annual variations of the same variable. We consider that it is important to analyze the models through the TFP annual variation, as there is greater variability of data. In addition, after applying the logarithm, it is possible to interpret the estimates as annual growth rates (Greene, 2003). Therefore, the $S F^{m}$ and $S F^{m}$ variables of the countries were transformed and reorganized in the same way. The Figure 1 demonstrates the scope of the method of this paper.

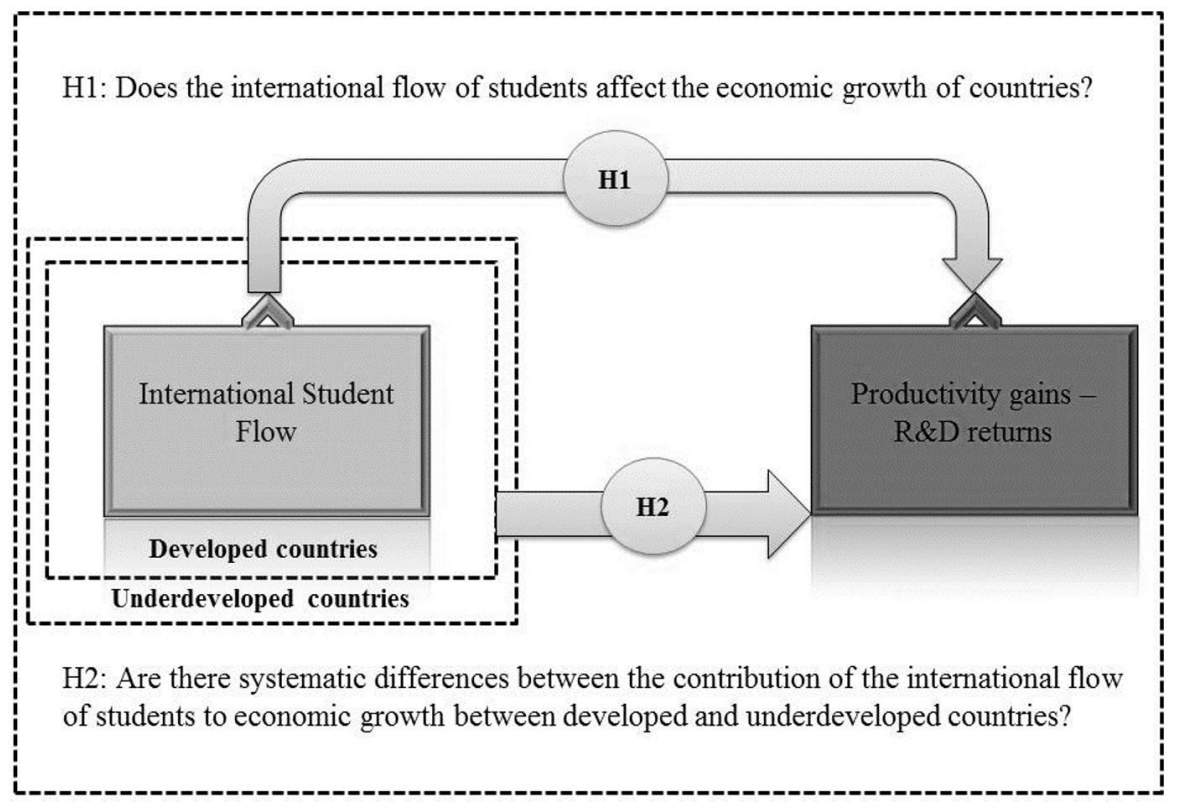

Figure 1. Scope of paper. Source: Prepared by the authors (2018). 


\section{Empirical findings}

This paper analyses whether R\&D spillovers brought through the international flow of tertiary students is a significant explanatory variable when TFP is the dependent variable. In other words, this study assesses the significance of the relationship between TFP and this channel of R\&D spillovers. This article uses econometric techniques, such as panel data analysis. In addition, the study does not use interpolated data, and missing values are treated as such. Also, 16 countries from the dataset had gaps in their time series, from a total of 87 nations. The summary statistics of the variables considered in this study is presented in Table 1.

Table 1. Summary statistics and correlations (time series from 2001-2012).

\begin{tabular}{|c|c|c|c|c|c|c|c|}
\hline \multirow{2}{*}{ Variable } & \multirow{2}{*}{ Mean } & \multirow{2}{*}{$\begin{array}{l}\text { Standart } \\
\text { Deviation }\end{array}$} & \multicolumn{5}{|c|}{ Correlation } \\
\hline & & & $\ddot{A} \ln T F P$ & $\ddot{A} \ln S F_{i t}^{f}$ & $\ddot{A} \ln S F_{i t}^{m}$ & $\ddot{A} F i t / L_{i t}$ & $\ddot{A} M i t /$ Yit \\
\hline$\ddot{A} \operatorname{lnTFP}$ & 0.476 & 4.0029 & 1 & & & & \\
\hline$\ddot{A} \ln S F_{i t}^{f}$ & 0.0015 & 0.00945 & 0.0286 & 1 & & & \\
\hline$\ddot{A} \ln S F_{i t}^{m}$ & 0.0078 & 0.0686 & 0.0572 & -0.1005 & 1 & & \\
\hline$\ddot{A F i t} / L_{i t}$ & 0.0357 & 0.1391 & 0.0505 & 0.5239 & 0.0146 & 1 & \\
\hline$\ddot{A M i t}$ / Yit & 0.3972 & 0.2393 & -0.0293 & 0.0122 & -0.0027 & -0.0283 & 1 \\
\hline
\end{tabular}

Source: Prepared by the authors (2018).

A unit root test was performed, with lags of one period, using the four methods proposed by Choi (2001). The tests involve inverted chi-square, inverted normal, inverted logit transform, and a modification of inverted chi-square. The null hypothesis was rejected for all the variables considered in this study. However, it is straightforward to notice that the variables $\ddot{A} l n S F_{i t}^{f}$ and $\ddot{A} \frac{F_{i t}}{L_{i t}}$ are highly correlated ( $\rho$ value $=0.000$ considering the regression $\ddot{A} \ln S F_{i t}^{f}=\beta_{1} \ddot{A} \frac{F_{i t}}{L_{i t}}$ ), due to the fact that they use similar data gathering methods. As the constructed variable $\ddot{A} l n S F_{i t}^{f}$ uses more information in its composition (considers not only total number of students abroad, but where the internationalization period occurred), this study will opt to exclude variable $\ddot{A} \frac{F_{i t}}{L_{i t}}$ from the panel
data analysis.

The Hausman test returned a $p$ value of 0.4245 , failing to reject statistically significant differences between the fixed and random effects models. According to Cameron \& Trivedi (2009), a random effects model, with panel-specific serial correlations and heteroscedasticity corrections was employed. Thus, the applied estimation method uses FGLS considering the autocorrelation process of each specific entity, as presented in Equation 11.

$$
\varepsilon_{i t}=\rho_{i} \varepsilon_{i, t-1}+u_{i t}
$$

The results are presented in Table 2.

Table 2. Total Factor Productivity estimation results (time series from 2001-2012 for 87 countries with 971 observations.

\begin{tabular}{|c|c|c|c|c|c|}
\hline \multirow{2}{*}{ Variables } & \multicolumn{5}{|c|}{ Models } \\
\hline & (1) & (2) & (3) & (4) & (5) \\
\hline \multirow{2}{*}{$\ddot{A} \ln S F_{i t}^{f}$} & $26.20511^{* * *}$ & & $23.08432^{* *}$ & $24.2152^{* * *}$ & $20.78455^{* *}$ \\
\hline & (9.326863) & & (9.639583) & (9.487789) & (9.801294) \\
\hline \multirow{2}{*}{$\ddot{A} \operatorname{lnS} F_{i t}^{m}$} & & $3.783216^{* * *}$ & $3.591395^{* * * *}$ & & $3.7147^{* * * *}$ \\
\hline & & (1.783216) & (1.401101) & & (1.402491) \\
\hline \multirow{2}{*}{$\ddot{A M i t} /$ Yit } & & -0.5297247 & $-0.6350272^{* * *}$ & & $-0.6421582^{* * *}$ \\
\hline & & (0.3431999) & (0.23879) & & $(0.2408426)$ \\
\hline \multirow{2}{*}{$\ddot{A M i t}$ / Yitx ÄlnSF $F_{i t}^{m}$} & & -3.655539 & -3.213337 & & -3.300243 \\
\hline & & (2.371007) & $(2.47381)$ & & $(2.484286)$ \\
\hline \multirow{2}{*}{ BRICS } & & & & -0.4846495 & -0.5131246 \\
\hline & & & & $(0.4722838)$ & $(0.4232872)$ \\
\hline \multirow{2}{*}{$B R I C S x \Delta \ln S F_{i t}^{f}$} & & & & $111.4189^{*}$ & $112.7936^{*}$ \\
\hline & & & & (60.14785) & (58.9202) \\
\hline
\end{tabular}

Note: Dependent variable is logTFP. All equations include a constant term, which was omitted. Panel-specific heteroscedasticity-corrected standard errors are presented in parentheses; **** and ${ }^{* * *}$ indicate parameters which are significant at $10 \%, 5 \%$ and $1 \%$, respectively. 
Equation 1 shows that students can be a significant channel of R\&D spillovers between countries, also shown in the papers of Le (2010) and Park (2004). As in previous studies, Equation 2 supports Coe and Helpman's hypothesis of R\&D spillovers through international trade. Equation 3 brings both the effects of internationalization of students and international trade altogether, also highlighting the significance of both initiatives for spillover occurrence. Equation 4 also includes the BRICS dummy variable, as well as its interaction with $S F_{i t}^{f}$. Our findings support the hypothesis that the BRICS community may benefit more than the rest of the nations considered in this study, although the significance should be further tested $(\rho$ value $=0.064)$. Equation 5 includes all variables, and also point towards the hypothesis of above-average benefits for the BRICS ( $\rho$ value $=0.056$ ).

The results found were consistent with the previous - albeit small - literature in the field. The variable created to capture R\&D spillovers through international flow of students was significant in every regression analyzed. More importantly, the results point towards an above-average benefit for the BRICS countries, as captured in Equations 4 and 5. Even though they were marginally significant at the 5\% level, both equations indicate that they positively benefit (i.e., their productivity gains are greater, when compared to the rest of the countries considered in this analysis). Furthermore, the study is in accordance with previous literature in spillover dissemination, as it also found consistent evidence of R\&D spillovers through international trade, a channel exhaustively studied in previous papers.

\section{Conclusion}

This study revisits previous efforts of assessing an important new channel of R\&D spillovers between countries: the international flow of students. Using more data, from a wider variety of countries, as well as with a bigger time series, the study assessed whether previous results would be sustained with the new data, as well as tried to identify if a very important - geopolitically speaking - group of nations could actually benefit more from such endeavors. The evidence pointing towards bigger R\&D spillovers for the BRICS community has important policy implications. In 2011, the Brazilian government approved an internationalization program aimed at allocating 100,000 students in foreign universities until 2015. Although the goal was not achieved (approximately 85,000 students were sent abroad), it shows important concerns related to the benefits of student internationalization.

In this sense, this article contributed to the understanding of the impact of international students flow to R\&D spillovers between countries. This finding is important to justify public policies in this area. Furthermore, we found both effects of internationalization of students and international trade. Moreover, the estimative of this article presented a significant effect to the BRICS countries, which contributes to the international literature. One limitation of this study is not considering a microregional level, which can improve the number of observations and contribute to the understanding of this phenomena in different regions at the same country. Future studies can contribute applying this method with a microregional database and geographical models.

The mobility of international students is currently an important political issue in the world. These formal or informal links between agents from diverse countries result in an exchange of ideas, experiences and knowledge potentially generating new business opportunities for developing economies.

This study can also be seen through the lens of assessing the economic returns of academic internationalization programs: for instance, the Brazilian government investment in such aforementioned program was over U\$ 1 billion, and there was not a consistent metric to evaluate whether the investment brought the appropriate returns. Moreover, China is, due to its huge population and increasing economic importance, the country with the biggest international student's community, showing internationalization efforts since Deng Xiaoping's government, as stated by Chen (2011). With almost half of the world's population and one fifth of its GDP, internationalization policies can be extremely fruitful efforts for the BRICS nations.

\section{Acknowledgements}

This work was supported by FAPESP Foundation. The second author would like to express his gratitude for the financial support of Coordenação de Aperfeiçoamento de Pessoal de Nível Superior (CAPES) (Process nº. 88887.161388/2017-00), the Lions-Club-Förderpreis (Stuttgart/Germany) and the Friedrich-Naumann-Stiftung für die Freiheit.

\section{References}

Abdih, Y., \& Joutz, F. L. (2006). Relation the knowledge production function to total factor productivity: an endogenous growth puzzle (IMF Working Paper, pp. 242-271). Washington: International Monetary Fund. 
Abreu, M., Groot, H. L. F. D., \& Florax, R. J. G. M. (2004). Spatial patters of technology diffusion: an empirical analysis using TFP (Discussion Paper, No. 4-079/3). The Netherlands: Tinbergen Institute.

Abubakar, Y. A., \& Mitra, J. (2017). Knowledge spillovers and high-impact growth: comparing local and foreign firms in the UK. Journal of International Entrepreneurship, 15(2), 145-176. http://dx.doi.org/10.1007/s10843-016-0195-7.

Acemoglu, D. (2009). Introduction to modern economic growth. Princeton: Princeton University Press.

Aghion, P., \& Howitt, P. (2009). The economics of growth. Cambridge: The MIT Press.

Aiyar, S., \& Dalgaard, C. J. (2005). Total factor productivity revisited: a dual approach to development accounting. IMF Staff Papers, 52(1), 82-102.

Atella, V., \& Quintieri, B. (2001). Do R\&D expenditures really matter for TFP? Applied Economics, 33(11), 1385-1389. http://dx.doi. org/10.1080/00036840010007939.

Audretsch, D. B., \& Feldman, M. P. (1996). R\&D spillovers and the geography of innovation and production. The American Economic Review, 86(3), 630-640.

Baier Junior, S. L., \& Tamura, R. (2002). How important are capital and total factor productivity for economic growth? (Working Paper). Atlanta: Federal Reserve Bank of Atlanta.

Baldacci, Clements, B., Gupta, S., \& Cui, Q. (2008). Social spending, human capital and growth in developing countries. World Development, 36(8), 1317-1341. http://dx.doi.org/10.1016/j.worlddev.2007.08.003.

Baldwin, R. E., Braconier, H., \& Forslid, R. (2005). Multinationals, endogenous growth and technological spillovers: theory and evidence. Review of International Economics, 13(5), 945-963. http://dx.doi.org/10.1111/j.1467-9396.2005.00546.x.

Bauer, P. (1988). Decomposing TFP growth in the presence of cost inefficiency, nonconstant returns to scale, and technological progress (Vol. 8813, 20 p.). Cleveland: Federal Reserve Bank of Cleveland.

Baumont, C., Ertur, C., \& Gallo, J. L. (2001). A spatial econometric analysis of geographic spillovers and growth for european regions, 1980-1995. Paris: Centre National de la Recherche Scientifique.

Bayoumi, T., Coe, D. T., \& Helpman, E. (1999). R\&D spillovers and global growth. Journal of International Economics, 47(2), $399-428$. http://dx.doi.org/10.1016/S0022-1996(98)00018-X.

Belitz, H., \& Mölders, F. (2016). International knowledge spillovers through high-tech imports and R\&D of foreign-owned firms. The Journal of International Trade \& Economic Development, 25(4), 590-613. http://dx.doi.org/10.1080/09638199.2015.1106575.

Benhabib, J., \& Spiegel, M. M. (1994). The role of human capital in economic development: evidence from aggregate cross-country data. Journal of Monetary Economics, 34(2), 143-173. http://dx.doi.org/10.1016/0304-3932(94)90047-7.

Bitzer, J., \& Geishecker, 1. (2006). What drives trade-related R\&D spillovers? Decomposing knowledge-diffusing trade flows. Economics Letters, 93(1), 52-57. http://dx.doi.org/10.1016/j.econlet.2006.03.051.

Bitzer, J., \& Kerekes, M. (2008). Does foreign direct investment transfer technology across borders? New evidence. Economics Letters, 100(3), 355-358. http://dx.doi.org/10.1016/j.econlet.2008.02.029.

Borensztein, E., Gregorio, J. D., \& Lee, J.-W. (1998). How does foreign direct investment affect economic growth? Journal of International Economics, 45(1), 115-135. http://dx.doi.org/10.1016/S0022-1996(97)00033-0.

Breschi, S., \& Lissoni, F. (2001). Knowledge spillovers and local innovation systems: a critical survey. Industrial and Corporate Change, 10(4), 975-1005.

Brun, J. F., Combes, J. L., \& Renard, M. F. (2002). Are there spillover effects between coastal and noncoastal regions in China? China Economic Review, 43(2), 161-169. http://dx.doi.org/10.1016/S1043-951X(02)00070-6.

Cameron, A. C., \& Trivedi, P. K. (2009). Microeconometrics using stata (706 p.). USA: Stata Press Books.

Cameron, G., Proudman, J., \& Redding, S. (2005). Technological convergence, R\&D, trade and productivity growth. European Economic Review, 49(3), 775-807. http://dx.doi.org/10.1016/S0014-2921(03)00070-9.

Carlino, G. A., Chatterjee, S., \& Hunt, R. M. (2001). Knowledge spillovers: cities' role in the new economy. Business Review Q, 4, $17-24$. http://dx.doi.org/10.21799/frbp.wp.

Chen, D. (2011). Internationalization of higher education in China and its development direction. Higher Education Studies, 1(1), 79-83.

Chen, E. K. (1997). The total factor productivity debate: determinants of economic growth in east Asia. Asian-Pacific Economic Literature, 11(1), 18-38. http://dx.doi.org/10.1111/1467-8411.00002.

Choi, 1. (2001). Unit root tests for panel data. Journal of International Money and Finance, 20(2), 249-272. http://dx.doi.org/10.1016/ S0261-5606(00)00048-6.

Coe, D. T., \& Helpman, E. (1995). International R\&D spillovers. European Economic Review, 39(5), 859-887. http://dx.doi.org/10.1016/00142921(94)00100-E.

Coelli, T. J., \& Rao, D. S. (2005). Total factor productivity growth in agriculture: a malmquist index analysis of 93 countries. Agricultural Economics, 32(1), 115-134. http://dx.doi.org/10.1111/j.0169-5150.2004.00018.x.

Cohen, W. M., \& Levinthal, D. A. (1990). Absorptive capacity: a new perspective on learning and innovation. Administrative Science Quarterly, 35(1), 128-152. http://dx.doi.org/10.2307/2393553.

Comin, D. (2006). Total factor productivity. An eponymous dictionary of economics. In S. Derlauf \& L. Blum (Eds.), In the new palgrave dictionary of economics (2nd ed., pp. 1-5). Hampshire: Palgrave Macmillan.

Di Liberto, A., Pigliaru, F., \& Mura, R. (2008). How to measure the unobservable: a panel technique for the analysis of TFP convergence. Oxford Economic Papers, 60(2), 343-368. http://dx.doi.org/10.1093/oep/gpm022.

Escribano, A., Fosfuri, A., \& Tribó, J. A. (2009). Managing external knowledge flows: the moderating role of absorptive capacity. Research Policy, 38(1), 96-105. http://dx.doi.org/10.1016/j.respol.2008.10.022.

Feenstra, R. C., Li, Z., \& Yu, M. (2014). Exports and credit constraints under incomplete information: theory and evidence to China. The Review of Economics and Statistics, 96(4), 729-744. http://dx.doi.org/10.1162/REST_a_00405. 
Felema, J., Raiher, A. P., \& Ferreira, C. R. (2013). Agropecuária brasileira: desempenho regional e determinantes de produtividade. Revista de Economia e Sociologia Rural, 51(3), 555-574. http://dx.doi.org/10.1590/S0103-20032013000300008.

Felipe, J. (2000). On the myth and mystery of Singapore's Zero TFP. Asian Economic Journal, 14(2), 187-209. http://dx.doi. org/10.1111/1467-8381.00108.

Ferrara, E. L., \& Marcellino, M. (2000). TFP, costs and public infrastructure: an equivocal relationship (IGIER Working Paper, No. 176). USA: SSRN.

Ferraz, D., Costa, N. J. D., Fernandes, B., Silva, E. P., Marques, P. H. M., Moralles, H. F., \& Rebelatto, D. (2018a). Analysis of absorptive capacity and foreign direct investment in the productivity of Brazilian municipalities. Production, 28(0), 28. http://dx.doi. org/10.1590/0103-6513.20180050.

Ferraz, D., Moralles, H. F., Campoli, J. S., Oliveira, F. C. R. D., \& Rebelatto, D. A. D. N. (2018b). Economic complexity and human development: DEA performance measurement in Asia and Latin America. Gestão \& Produção, 25(4), 839-853. http://dx.doi. org/10.1590/0104-530x3925-18.

Fischer, M. M., \& Varga, A. (2003). Spatial knowledge spillovers and university research: evidence from Austria. The Annals of Regional Science, 372), 303-322. http://dx.doi.org/10.1007/s001680200115.

Fleisher, B., Li, H., \& Zhao, M. Q. (2010). Human capital, economic growth, and regional inequality in China. Journal of Development Economics, 92(2), 215-231. http://dx.doi.org/10.1016/j.jdeveco.2009.01.010.

Frantzen, D. (2000). R\&D, human capital and international technology spillovers: a cross-country analysis. The Scandinavian Journal of Economics, 102(1), 57-75. http://dx.doi.org/10.1111/1467-9442.00184.

Fritsch, M., \& Franke, G. (2004). Innovation, regional knowledge spillovers and R\&D cooperation. Research Policy, 33(2), $245-255$. http://dx.doi.org/10.1016/S0048-7333(03)00123-9.

Fujiwara, A. (2017). The knowledge spillover resulting from the mobility of knowledge workers. In: Proceedings of the 6th International Conference on Industrial Technology and Management. USA: IEEE. http://dx.doi.org/10.1109/1CITM.2017.7917918.

Glaeser, E. L., Scheinkman, J. A., \& Shleifer, A. (1995). Economic growth in a cross-section of cities. Journal of Monetary Economics, 36(1), 117-143. http://dx.doi.org/10.1016/0304-3932(95)01206-2.

Greene, W. H. (2003). Econometric analysis. Chennai, Tamil Nadu: Pearson Education India.

Griffith, R., Huergo, E., Mairesse, J., \& Peters, B. (2006). Innovation and productivity across four european countries. Oxford Review of Economic Policy, 22(4), 483-498. http://dx.doi.org/10.1093/oxrep/grj028.

Griffith, R., Redding, S., \& Reenen, J. V. (2003). R\&D and absorptive capacity: theory and empirical evidence. The Scandinavian Journal of Economics, 105(1), 99-118. http://dx.doi.org/10.1111/1467-9442.00007.

Griffith, R., Redding, S., \& Van Reenen, J. (2004). Mapping the two faces of R\&D: productivity growth in a panel of OECD industries. The Review of Economics and Statistics, 86(4), 883-895. http://dx.doi.org/10.1162/0034653043125194.

Grossman, G. M., \& Helpman, E. (1991). Trade, knowledge spillovers, and growth. European Economic Review, 35(2-3), 517-526. http:// dx.doi.org/10.1016/0014-2921(91)90153-A.

Haaland, J. 1., \& Kind, H. K. (2008). R\&D policies, trade and process innovation. Journal of International Economics, 74(1), $170-187$. http://dx.doi.org/10.1016/j.jinteco.2007.04.001.

Hall, B. H., \& Mairesse, J. (1995). Exploring the relationship between R\&D and productivity in french manufacturing firms. Journal of Econometrics, 65(1), 263-293. http://dx.doi.org/10.1016/0304-4076(94)01604-X.

Harhoff, D. (1998). R\&D and productivity in german manufacturing firms. Economics of Innovation and New Technology, 6(1), 29-50. http://dx.doi.org/10.1080/10438599800000012.

Hulten, C. R. (2001). Total factor productivity: a short biography. In C. R. Hulten, E. R. Dean and M. J. Harper. New developments in productivity analysis. Chicago: University of Chicago Press. http://dx.doi.org/10.7208/chicago/9780226360645.003.0001.

Isaksson, A. (2007). Determinants of total factor productivity: a literature review. Resarch and statistics branch. Viena: United Nations Industrial Development Organization.

Jeong, H., \& Townsend, R. M. (2007). Sources of TFP growth: occupational choice and financial deepening. Economic Theory, 32(1), 179-221. http://dx.doi.org/10.1007/s00199-006-0201-8.

Kalirajan, K. P., Obwona, M. B., \& Zhao, S. (1996). A decomposition of total factor productivity growth: the case of chinese agricultural growth before and after reforms. American Journal of Agricultural Economics, 78(2), 331-338. http://dx.doi.org/10.2307/1243706.

Keller, W., \& Yeaple, S. R. (2009). Multinational enterprises, international trade, and productivity growth: firm level evidence from the United States. The Review of Economics and Statistics, 91(4), 821-831. http://dx.doi.org/10.1162/rest.91.4.821.

Konno, T. (2016). Knowledge spillover processes as complex networks. Physica A, 462, 1207-1214. http://dx.doi.org/10.1016/j. physa.2016.06.124.

Le, T. (2008). "Brain Drain” or "Brain Circulation": evidence From OECD’s International Migration and R\&D Spillovers. Main, 55(5), 618-636. http://dx.doi.org/10.1111/j.1467-9485.2008.00468.x.

Le, T. (2010). Are student flows a significant channel of R\&D spillovers from the north to the south? Economics Letters, 107(3), 315317. http://dx.doi.org/10.1016/j.econlet.2009.12.018.

Le, T. (2012). R\&D spillovers through student flows, institutions, and economic growth: what can we learn from African countries? Scottish Journal of Political Economy, 59(1), 115-130. http://dx.doi.org/10.1111/j.1467-9485.2011.00571.x.

Lee, G. (2005). Direct versus Indirect International R\&D Spillovers. Information Economics and Policy, 17(3), 334-348. http://dx.doi. org/10.1016/j.infoecopol.2004.12.001.

Li, X. (2011). Sources of external technology, absorptive capacity, and innovation capability in chinese state-owned high-tech enterprises. World Development, 39(7), 1240-1248. http://dx.doi.org/10.1016/j.worlddev.2010.05.011.

Lichtenberg, F. R., \& Pottelsberghe de la Potterie, B. (1998). International R\&D spillovers: a comment. European Economic Review, 42(8), 1483-1491. http://dx.doi.org/10.1016/S0014-2921(97)00089-5. 
Lin, T. C. (2003). Education, technocal progress and economic growth: the case of Taiwan. Economics of Education Review, 22(2), 213-220. http://dx.doi.org/10.1016/S0272-7757(02)00030-4.

Lipsey, R. G., \& Carlaw, K. (2000). What does total factor productivity measure? International Productivity Monitor, 1, 31-40.

Lipsey, R. G., \& Carlaw, K. 1. (2004). Total factor productivity and the measurement of technological change. The Canadian Journal of Economics. Revue Canadienne d'Economique, 37(4), 1118-1150. http://dx.doi.org/10.1111/j.0008-4085.2004.00263.x.

Liu, X., \& Buck, T. (2007). Innovation performance and channels for international technology spillovers: evidence from chinese hightech industries. Research Policy, 36(3), 355-366. http://dx.doi.org/10.1016/j.respol.2006.12.003.

Luintel, K. B., \& Khan, M. (2017). ldeas production and international knowledge spillovers: digging deeper into emerging countries. Research Policy, 46(10), 1738-1754. http://dx.doi.org/10.1016/j.respol.2017.07.009.

Lumenga-Neso, O., Olarreaga, M., \& Schiff, M. (2005). On indirect trade-related R\&D spillovers. European Economic Review, 49(7), 1785-1798. http://dx.doi.org/10.1016/j.euroecorev.2004.06.004.

Madsen, J. B. (2007). Technology spillover through trade and TFP convergence: 120 years of evidence for the OECD countries. Journal of International Economics, 72(2), 464-480. http://dx.doi.org/10.1016/j.jinteco.2006.12.001.

Madsen, J. B. (2008). Economic growth, TFP convergence and the world export of ideas: a century of evidence. The Scandinavian Journal of Economics, 110(1), 145-167. http://dx.doi.org/10.1111/j.1467-9442.2008.00530.x.

Marshall, A. (1961). Principles of economics (9th ed.). London: Macmillan.

Maudos, J., Pastor, J. M., \& Seranno, L. (1999). Total factor productivity measurement and human capital in OECD countries. Economics Letters, 6(6), 389-392. http://dx.doi.org/10.1080/135048599353159.

Maurseth, P. B., \& Verspagen, B. (2002). Knowledge spillovers in europe: a patent citations analysis. The Scandinavian Journal of Economics, 104(4), 531-545. http://dx.doi.org/10.1111/1467-9442.00300.

Mendi, P. (2007). Trade in disembodied technology and total factor productivity in OECD countries. Research Policy, 36(1), 121-133. http://dx.doi.org/10.1016/j.respol.2006.09.028.

Messa, A. (2013). Indicadores de produtividade: Uma breve revisão dos principais métodos de cálculo. Radar: Tecnologia. Produção e Comércio Exterior, 28, 2013.

Miller, S. M., \& Upadhyay, M. P. (2002). Total factor productivity and the convergence hypothesis. Journal of Macroeconomics, 24(2), 267-286. http://dx.doi.org/10.1016/S0164-0704(02)00022-8.

Moralles, H. F., \& Rebelatto, D. A. N. (2016). The effects and time lags of R\&D spillovers in Brazil. Technology in Society, 47, 148-155. http://dx.doi.org/10.1016/j.techsoc.2016.10.002.

Moralles, H. F., Rebelatto, D. A. N., \& Sartoris, A. (2013). Parametric VaR with goodness-of-fit tests based on EDF statistics for extreme returns. Mathematical and Computer Modelling, 58(9-10), 1648-1658.

Narula, R., \& Marin, A. (2003). FDI spillovers, absorptive capacities and human capital development: evidence from Argentina (MERIT - Infonomics Research Memorandum Series). The Netherlands: Merit.

Nordhaus, W. D., \& Samuelson, P. (2012). Economía (19. ed.). Porto Alegre: AMGH Editora.

Oketch, M. 0. (2006). Determinants of human capital formation and economic growth of african countries. Economics of Education Review, 25(5), 554-564. http://dx.doi.org/10.1016/j.econedurev.2005.07.003.

Park, J. (2004). International student flows and R\&D spillovers. Economics Letters, 82(3), 315-320. http://dx.doi.org/10.1016/j. econlet.2003.07.012.

Park, J. (2006). Dispersion of human capital and economic growth. Journal of Macroeconomics, 28(3), 520-539. http://dx.doi. org/10.1016/j.jmacro.2004.09.004.

Ponds, R., Oort, F. V., \& Frenken, K. (2010). Innovation, spillovers and university-industry collaboration: an extended knowledge production function approach. Journal of Economic Geography, 10(2), 231-255. http://dx.doi.org/10.1093/jeg/lbp036.

Qiu, S., Liu, X., \& Gao, T. (2017). Do emerging countries prefer local knowledge or distant knowledge? Spillover effect of university collaborations on local firms. Research Policy, 46(7), 1299-1311. http://dx.doi.org/10.1016/j.respol.2017.06.001.

Rodríguez-Gulias, M. J., Rodeiro-Pazos, D., \& Fernández-López, S. (2017). The effect of university and regional knowledge spillovers on firms' performance: an analysis of the Spanish USOs. The International Entrepreneurship and Management Journal, 13(1), 191-209. http://dx.doi.org/10.1007/s11365-016-0399-2.

Rudd, J. B. (2000). Empirical evidence on human capital spillovers. USA: Federal Reserve Board.

Seetanah, B. (2009). The economic importance of education. Journal of Applied Econometrics, 12(1), 137-157.

Self, S., \& Grabowski, R. (2003). Education and long-run development in Japan. Journal of Asian Economics, 14(4), 565-580. http:// dx.doi.org/10.1016/S1049-0078(03)00095-2.

Self, S., \& Grabowski, R. (2004). Does education at all levels cause growth? India, a case study. Economics of Education Review, 23(1), 47-55. http://dx.doi.org/10.1016/S0272-7757(03)00045-1.

Spulber, D. F. (2008). Innovation and international trade in technology. Journal of Economic Theory, 138(1), 1-20.

Tang, L., \& Koveos, P. E. (2008). Embodied and disembodied R\&D spillovers to developed and developing countries. International Business Review, 17(5), 546-558. http://dx.doi.org/10.1016/j.ibusrev.2008.03.002.

Verspagen, B. (1995). R\&D and productivity: a broad cross-section cross-country look. Journal of Productivity Analysis, 6(2), 117-135. http://dx.doi.org/10.1007/BF01073407.

Vinding, A. L. (2006). Absorptive capacity and innovative performance: a human capital approach. Economics of Innovation and New Technology, 15(4-5), 507-517. http://dx.doi.org/10.1080/10438590500513057.

Waheed, A. (2017). Innovation and firm-level productivity: evidence from Bangladesh. The Developing Economies, 55(4), $290-314$. http://dx.doi.org/10.1111/deve.12152.

Wang, C. C., \& Wu, A. (2016). Geographical FDI knowledge spillover and innovation of indigenous firms in China. International Business Review, 25(4), 895-906. 
Weil, D. (2012). Economic growth (3rd ed.). Harlow: Pearson Education Limited.

Wennberg, K., Wiklund, J., \& Wright, M. (2011). The effectiveness of university knowledge spillovers: performance differences between university spinoffs and corporate spinoffs. Research Policy, 4O(8), 1128-1143. http://dx.doi.org/10.1016/j.respol.2011.05.014.

Wolff, E. N. (2000). Human capital investment and economic growth: exploring the cross-contry evidence. Structural Change and Economic Dynamics, 11(4), 433-472. http://dx.doi.org/10.1016/S0954-349X(00)00030-8.

$\mathrm{Yu}, \mathrm{H}$. (2017). Networking China: the digital transformation of the chinese economy (pp. 817-819). Chicago: University of 11 linois Press.

Zhang, C., \& Zhuang, L. (2011). The composition of human capital and economic growth: evidence from China using dynamic panel data. China Economic Review, 22(1), 165-171. http://dx.doi.org/10.1016/j.chieco.2010.11.001.

Zhang, H., Patton, D., \& Kenney, M. (2013). Building global-class universities: assessing the impact of the 985 project. Research Policy, 42(3), 765-775. http://dx.doi.org/10.1016/j.respol.2012.10.003. 
Appendix A. Countries included in the sample.

DEVELOPED COUNTRIES CONSIDERED: Australia, Austria, Belgium, Canada, Czech Republic, Denmark, Finland, France, Germany, Hungary, Ireland, Italy, Japan, Netherlands, New Zealand, Norway, Poland, Portugal, Republic of Korea, Spain, Sweden, United Kingdom, United States.

REMAINING COUNTRIES: Algeria, Argentina, Bangladesh, Belarus, Bolivia, Brazil, Bulgaria, Cameroon, Chile, China, Colombia, Croatia, Ecuador, Egypt, Estonia, Ethiopia, Georgia, Ghana, Greece, Guatemala, Hungary, lceland, India, Indonesia, Iran, Iraq, Israel, Jordan, Kazakhstan, Kenya, Kuwait, Latvia, Lithuania, Malaysia, Mexico, Morocco, Mozambique, Nigeria, Pakistan, Peru, Philippines, Romania, Russia, Saudi Arabia, Slovakia, Slovenia, South Africa, Sri Lanka, Sudan, Switzerland, Syria, Tanzania, Thailand, Tunisia, Turkey, Uganda, Ukraine, United Arab Emirates, Uruguay, Uzbekistan, Venezuela, Viet Nam, Zimbabwe. 